\title{
Sağlık Otelciliğinde Hizmet Kalitesinin Marka Performansı Üzerine Etkisi
}

\section{The Effect of Service Quality on Brand Performance on Healthcare Hospitality Services}

\author{
Öğr. Gör. Dr. Çiğdem Unurlu ${ }^{1}$
}

Başvuru Tarihi: 06.07.2018

Kabul Tarihi: 23.12.2019

\section{Öz}

Üretilen mal ve hizmetlerin tüketicilerin beklentilerini karşılama derecesi olarak nitelendirilen hizmet kalitesinin hastane otelciliğinde kilit bir rolü bulunmaktadır. Bu bakımdan çalışmanın amacı, hastaların bakış açısından sağlık otelciliğinde hizmet kalitesini ölçmek ve hizmet kalitesinin hastanenin performansina olan etkisini tespit etmektir. Bu amaçla, 2018 yll içerisinde Edirne, Çorlu ve Tekirdăg'da bulunan özel ve kamu hastanelerinden hizmet almış 500 kişiye soru formu dağıtılmıştır. Kolayda örnekleme ve yüz yüze anket yöntemi ile toplam 412 analiz edilebilir anket elde edilmiştir. Verilerin analizinde öncelikle ölçeklerin her biri için bir dizi faktör analizi yapılmış, sonrasında ise araştırma kapsamında önerilen model çoklu regresyon analizi ile test edilmiştir. Regresyon analizi sonucunda hizmet kalitesinin marka performansindaki değişkenliğin \%66’sını açıkladiğı ve marka performansındaki değişkenliği açıklayan boyutların önem sirasıyla fiziki kaynaklar (\%25), empati (\%23), yeteneklilik (\%19), heveslilik (\%16) ve güvenirlilik (\%11) olduğu tespit edilmiştir.

Anahtar Kelimeler: Hizmet Kalitesi, Marka Performansı, Sağlık Otelciliği

\section{Abstract}

There are a few studies indicating the importance of the service quality in healthcare hospitality services which is defined as the level of meeting the consumers' expectation of the produced goods and services. In this regard, the aim of this study is to measure the service quality in healthcare hospitality services from the viewpoint of patients and to determine the effect of the performance of the hospital on service quality. For this purpose, questionnaires were distributed to 500 people who received service from private and public hospitals in Edirne, Çorlu and Tekirda $\breve{g}$ in 2018. A total of 412 analyzable questionnaires were obtained by convenience sampling and face-to-face survey method. As a result of the analysis, it was found that service quality explained $66 \%$ of the variability in brand performance, and, it was found that service quality' dimensions of the explaining the variability in brand performance were respectively tangibles (25\%), empathy (23\%), competence (19\%), responsiveness (16\%) and reliability (11\%).

Keywords: Service Quality, Brand Performance, Healthcare Hospitality Services

\footnotetext{
1 Trakya Üniversitesi, Edirne Sosyal Bilimler MYO, unurlu.cigdem@gmail.com, ORCID: 0000-0001-5653-6013
} 


\section{Giriş}

Hizmetlerin pazarlanmasında olduğu gibi hizmetlerin kalitesinin değerlendirilmesinde de birtakım farklılıklar bulunmaktadır. Somut olmayan bir ürün olan hizmetlerde kalitenin değerlendirilmesinde yaşanan sıkıntıların en önemli nedenleri ürünlerin standartlaştırılamaması, ürünlerin heterojen olması ve tüketicinin üretim sürecine dahil olması gibi faktörler bulunmaktadır. Ayrıca verilen hizmetlerin soyutluluğu, üretim ve tüketimin eş zamanlılığı da bu ölçümü güçleştirmektedir. Satın alma sürecini zorlaştıran bu nitelikler, tüketicinin satın aldığı ürünün kalite ve performansını değerlendirmesini olumsuz yönde etkilemektedir. Nitekim Millar ve Tesser (1986) tüketici davranışlarının duygulardan ve bilişsel yargılardan oluştuğunu öne sürmektedir. Bu sebeple tüketici davranışlarında hangi duygu ve bilişsel yargıların daha baskın olduğunun tespit edilmesi işletmelerin pazarlama eylemlerinin başarısında son derece önemlidir. Bu veriler ışığında bileşik bir ürün olan hizmetler söz konu olduğunda, tüketicinin ürün ile ilgili kalite algısının oluşması ve satın aldığı markanın performansını değerlendirmesi daha da karmaşık hale gelmektedir. Diğer taraftan, Anderson ve Zeithamal (1984) hizmet kalitesi yüksek ürünlerin hizmet sektörünün etkinliğinin, verimliliğinin ve rekabet yeteneğinin artmasında son derece önemli bir role sahip olduğunu belirtmişlerdir.

Kalite kavramının daha iyi yorumlanabilmesi için kavramın üretici ve tüketicinin bakış açısından ayrı ayrı değerlendirilmesi gerekmektedir. Tüketici açısından kalite, satın alınan ürünlerin kulanım uygunluğu olarak değerlendirilirken; üretici açısından ise vaat edilen hizmetlerin tam zamanında ve kusursuz olarak verilmesini ifade etmektedir (Kotler ve Keller, 2012). Hizmet kalitesinin ölçümünde kullanılan pek çok model bulunmaktadır. Örneğin Gummesson (1987) ise kalitenin dizayn kalitesi, üretim-dağıtım kalitesi, ilişkisel kalite ve çıktının kalitesi olmak üzere dört boyuttan oluştuğunu belirtmiştir. Gummesson'un (1987) kalite modeli daha çok somut ürünlerin kalitesinin değerlendirilmesinde daha uygun olduğu düşünülmektedir. Cronin ve Taylor'un (1992) hizmet performansı modeli ise performans yönelimli bir kalite yaklaşımıdır.

Pazarlamada yaygın olarak araştırılan bir konu olan hizmet kalitesi ile ilgili farklı ölçüm yöntemleri ve ölçekler söz konusudur. Ölçümü yapılacak olan sektörün niteliği, katılımcıların kültürel özellikleri ölçümleri şekillendirmektedir. Bu bakımdan Bülbül ve Demirer (2008) Parasuraman vd.'nin (1985) hizmet kalitesi ölçeğinin her ne kadar evrensel bir ölçek olarak değerlendirilse de ölçeğin geçerliliğinin ve güvenirliliğinin farklı kültürlerde sınanması gerektiğini belirtmişlerdir. Nitekim 2008'den bu yana Türkiye'de farklı sektörlerde (Çetin ve Kuzucu, 2019; Dalgıç, 2013; Şahin ve Şen, 2017) hizmet kalitesi araştırılmıştır. Ancak sağlık sektöründe (Papatya, Papatya \& Hamşığlu, 2012; Akdağ vd., 2104; Demirer ve Bülbül, 2014; Neşe, Turan ve Çizmeci, 2017; Tarcan, Karahan \& Tarcan, 2018) hizmet kalitesini araştıran sınırlı sayıda çalışma bulunmaktadır. Bu nedenle bu çalışmanın öncelikle sağlık sektöründe ve Trakya Bölgesi'nde (Edirne, Çorlu ve Tekirdağ) gerçekleştirilmiş olması ölçeğin geçerlilik ve güvenirliliğinin farklı kültürlerde ve farklı sektörlerde test edilmesi bakımından önem taşımaktadır. Diğer taraftan çalışmanın en önemli sınırlılığı ise sonuçların yalnızca veri toplanan hastaneler için genelleştirilebileceğidir. Ayrıca Choi vd. (2004) sağlık sektöründe verilen hizmetlerde soyut olan pek çok unsurun bulunduğunu ve bu sebeple bu sektörde hizmet 
kalitesinin titizlikle ölçülmesi gerektiğini belirtmiştir. Hastaların bakış açısından sağlık otelciliğinde verilen hizmetlerin kalitesinin değerlendirilmesi henüz çok yaygın olmamakla birlikte (Choi vd., 2004), sağlık sektöründe marka performansının ölçüldüğü bu çalışmada tüketicilerin hastanelere ilişkin bilişsel tutumları değerlendirilmeye çalışılmıştır. Elde edilen sonuçların sağlık sektöründe yer alan işletmelere stratejik bir bakış açısı kazandıracağı düşünülmektedir.

\section{Hizmet Kalitesi}

Kotler (2000), kalite bakımından hizmetlerin somut mallardan ayrıldığını belirtmiştir. Bu durumun ise hizmetlerin soyut ve heterojen olmasından, depolanma özelliğinin olmamasından, hizmetlerde üretim ve tüketimin eş zamanlı olmasından kaynaklandığını belirtmiştir. Kotler ve Keller (2012), kaliteyi tüketiciler ve üreticiler açısından farklı değerlendirmişlerdir. Tüketici açısından kalite, satın alınan ürünlerin kullanım uygunluğu ya da ihtiyaçları giderebilme niteliği olarak değerlendirilirken; üretici açısından kalite, üretilen ürünlerin belirtilen ya da ima edilen ihtiyaçları giderilebilme özelliğine sahip ayırt edici tüm özellikleri olarak tanımlanmıştır. Bir başka ifade ile hizmet kalitesi, üretilen mal ve hizmetlerin tüketicilerin beklentilerini karşılama derecesi olarak da nitelendirilmektedir. Bununla birlikte Kotler ve Keller (2012), hizmet işletmelerinin kalitelerini daha çok fiziksel kanıtlarla ifade etmeye çalıştıklarını belirtmişlerdir. Bu yaklaşımda hizmetin gerçekleştiği fiziki ortam, iş görenler, kullanılan iletişim araçları, semboller ve fiyat gibi faktörler fiziksel kanıt olarak değerlendirilmektedir. Hizmet kalitesini ölçmeyi amaçlayan hizmet kalitesi modelleri Tablo 1'de yer almaktadır.

Hizmet kalitesi, hizmet pazarlaması alanında belki de en yaygın araştırılan konular arasında yer almaktadır. Ancak hizmet kalitesinin ölçümünde standart çıtılara ulaşmak henüz mümkün olmamaktadır. Nitekim kültürler, yerel birtakım nitelikler tüketicinin kalite ile ilgili algısını önemli ölçüde farklılaştırmaktadır. Bu bakımdan, Bülbül ve Demirer (2008), Türkçe literatürde hizmet kalitesi ölçeğini kullanarak hizmet kalitesini ölçmeyi amaçlayan araştırmaların geçerlilik ve güvenirliliğini onaylayan çok sayıda çalışma olmadığını belirtmişlerdir. Hizmet kalitesi ölçeği her ne kadar evrensel bir ölçek olsa da Parasuraman vd. (1985) ölçeğin güvenirliliğinin geliştirilmesi için farklı sektörlerde ve farklı kültürlerde test edilmesi gerektiğini öne sürmüştür (Bülbül ve Demirer, 2008). 


\section{Tablo 1. Hizmet Kalitesi Ölçme Modelleri}

\begin{tabular}{|c|c|}
\hline $\begin{array}{l}\text { Grönros'un (1984), } \\
\text { Toplam Algilanan Hizmet } \\
\text { Kalitesi Modeli }\end{array}$ & $\begin{array}{l}\text { Nordic Model olarak da anılan bu model; beklenen ve algılanan kalite } \\
\text { olmak üzere iki tür kaliteden oluşmaktadır. Yüksek düzeyde algılanan } \\
\text { kalite, gerçekleşen ve beklenen kalite eşleştiği zaman oluştuğu öne } \\
\text { sürülmüştür. }\end{array}$ \\
\hline $\begin{array}{l}\text { Parasuraman, Zeithaml ve } \\
\text { Berry'in (1985) Hizmet } \\
\text { Kalitesi Modeli (Servqual) }\end{array}$ & $\begin{array}{l}\text { Parasuraman vd. (1985), tüketici yönelimli bir hizmet kalitesi modeli } \\
\text { benimsemiştir. } \mathrm{Bu} \text { yaklaşımda tüketicinin hizmet kalitesini } \\
\text { değerlendirirken baz aldığı en temel unsurların güvenirlilik, heveslilik, } \\
\text { fiziki kaynaklar, yeteneklilik ve empati olduğu öne sürülmektedir. }\end{array}$ \\
\hline $\begin{array}{l}\text { Gummesson'un (1987) 4Q } \\
\text { Hizmet Kalitesi Modeli }\end{array}$ & $\begin{array}{l}\text { Müşteri bakımından algılanan kalitenin baz alındığı bu model; (1) } \\
\text { dizayn kalitesi, (2) üretim ve dağıtım kalitesi, (3) ilişkisel kalite ve (4) } \\
\text { çıktının kalitesi olmak üzere dört bileşenden oluşmaktadır. Bu } \\
\text { bileşenler müşterinin algıladığı hizmetin kalitesinin } \\
\text { değerlendirilmesinde kullanılmaktadır. }\end{array}$ \\
\hline $\begin{array}{l}\text { Grönross ve } \\
\text { Gummeson'un (1987) } \\
\text { "Sentezlenmis Kalite } \\
\text { Modeli" }\end{array}$ & $\begin{array}{l}\text { Sentezlenmiş kalite modeli, Gummesson'un 4Q Hizmet Kalitesi } \\
\text { Modeli ile Grönross'un Toplam Algılanan Hizmet Kalitesi Modeli'nin } \\
\text { birleştirilmiş halidir. Bu modelde Gummesson'un 4Q'suna ilaveten 2Q } \\
\text { daha eklenmiştir. Bunlar ise teknik kalite ve fonksiyonel kalite } \\
\text { şeklindedir. }\end{array}$ \\
\hline $\begin{array}{l}\text { 1) İyi- } \\
\text { deli }\end{array}$ & $\begin{array}{l}\text { Norman'ın (1991) geliştirmiş olduğu bu modelde; hizmet kalitesi } \\
\text { işletmelerde üretim sonucu elde edilen çıtıların iyi ve kötü kalite } \\
\text { halkaları içinde değerlendirilmesi sonucu oluşmaktadır. } \\
\text { Hizmetlerin aşırı soyutluluğu ve üretimde emek faktörünün rolü, } \\
\text { hizmet işletmelerinde çlktıların değişken olmasına neden olmaktadır. } \\
\text { Bu durum ise kalite yönetimi konusunda hizmet işletmelerini hassas } \\
\text { hale getirmektedir. Norman'ın (1991) kalite modelinde iyi ve kötü } \\
\text { kalitenin oluşmasına neden olabilecek durumlar bulunmaktadır. } \\
\text { Ayrıca, bu model kötü kaliteden iyi kaliteye geçişin yollarını da } \\
\text { barındırmaktadır. }\end{array}$ \\
\hline $\begin{array}{l}\text { Cronin ve Taylor'un } \\
\text { (1992) Servis Performansı } \\
\text { Modeli (Servperf) }\end{array}$ & $\begin{array}{l}\text { Cronin ve Taylor'un (1992) Servis Performansı modelinde, } \\
\text { Parasuraman vd. (1985) tarafından geliştirilen hizmet kalitesi yaklaşımı } \\
\text { yerine, beklenen ve algılanan kalite farkından oluşan performans } \\
\text { yönelimli bir yaklaşım benimsenmiştir. Bu modelde hizmet kalitesinin } \\
\text { tüketici tarafından algılanan performans ile ilgili olduğu } \\
\text { düşünülmektedir. Bir diğer ifade ile algılanan performans hizmet } \\
\text { kalitesi olarak değerlendirilmektedir. }\end{array}$ \\
\hline
\end{tabular}

Kaynak: Koçak, C.; Albayrak, S. A. ve Duman, N. B. (2014). Hemşirelerin Bakım Verici Rollerine Ilişsin Tutum Ỏç̧eğ Geliştirilmesi: Geçerlilik ve Güvenirlik Çalışması, Hemşirelikte Eğitim ve Araştırma Dergisi, 11(4): 16-21

Sağlık sektöründe verilen hizmetler somut unsurlar barındırsa da bu sektör hizmet kalitesinin ölçülmesinde ihtiyatlı olunması gereken bir sektördür. Nitekim hastaların sağlık hizmeti almaları ve aldıkları hizmeti değerlendirmeleri arasında önemli bir zaman ayrımı bulunmaktadır. Bu zaman alınan hizmetin değerlendirilmesi bakımından dikkate değerdir (Choi vd., 2004). Ancak Newcome (1997) ve Williams (1994) hastaların almış oldukları hizmetin kalitesini değerlendirme konusunda gerekli olan yetenek ve uzmanlıktan yoksun olduklarını belirtmişlerdir. Sonuç olarak hastalar hasta-doktor ilişkisi, hizmetin verildiği fiziki koşullar gibi deneyimsel süreçleri baz alarak hizmet kalitesini değerlendirmektedirler (Choi, 2004). Mucuk (2007, s. 307), hizmet kalitesi ölçeğinin alt boyutlarını kısaca söyle değerlendirmiştir: 
Fiziksel Kaynaklar: Verilen hizmet ile ilgili çalışanlar, kullanılan makine ve teçhizat, binanın dış görünüşü gibi fiziksel kanıtlardır.

Yeteneklilik: İşletmenin sahip olduğu insan kaynağının vaat edilen hizmetleri eksiksiz ve güvenilir bir biçimde yerine getirebilme yeteneğidir.

Heveslilik: İşletmenin sahip olduğu insan kaynağının müşterinin ihtiyaç duyduğu hizmeti tam ve zamanında vermeye hevesli ve istekli olmasıdır.

Güvenirlilik: İşletmenin sahip olduğu insan kaynağının müşteride güven duygusu uyandırması, nezaketi ve bilgili olması ile ilgilidir.

Empati: İşletmenin sahip olduğu insan kaynağının kendisini tüketicinin yerine koyabilmesi, tüketicinin beklenti ve ihtiyaçlarını anlamak için ve bu ihtiyaçları karşılayabilmek için özen, ilgi ve çaba göstermesidir.

Sağlık otelciliğinde hizmet kalitesini araştıran bir çalışmada hizmet kalitesi empati, karşılıklı saygı, hastaların dini ve hastalıklarıyla ilgili ihtiyaçları gibi boyutlar açısından değerlendirilmeye çalışılmıştır. Bu çalışmada somut unsurlar ise yiyecek içecek hizmetleri ve fiziki çevre olarak ele alınmıştır. Çalışma sonucunda hasta doktor ilişkisinde karşılıklı saygı probleminin olduğu, hastanın hastalığı ile ilgili ihtiyaçlarının karşılanmadığı sonucuna ulaşılmıştır. Ayrıca fiziki çevre ile ilgili hastaların memnuniyetsizlikler yaşadığı elde edilen sonuçlar arasında yer almaktadır (Tomes ve Ng, 1995). Hindistan' da özel hastanelerden hizmet alan hastalar üzerinde yapılan bir başka çalışmada ise hizmet kalitesinin yalnızca güvenirlilik ve heveslilik boyutlarının müşteri memnuniyeti üzerinde etkili olduğu; empati, fiziki kaynaklar ve yeteneklilik boyutlarının ise müşteri memnuniyeti üzerinde etkili olmadığı sonucuna ulaşılmıştır (Meesala ve Paul, 2018). Endonezya'da hastanelerden hizmet alan hastalar üzerinde yapılan bir başka çalışma ise hizmet kalitesinin empati boyutuna vurgu yapmış ve çalışanların hastalara karşı empati yeteneklerini daha fazla kullanmaları gerektiğini belirtmişlerdir (Handayani vd., 2015). Bir başka çalışmada ise hizmet kalitesi heveslilik, yeteneklilik, güven, fiziki kaynaklar, sağlık iletişimi ve hasta yönelimi olmak üzere altı boyutta değerlendirilmiştir. Çalışma sonucunda hizmet kalitesinin hastalarca en önemli boyutunun güven, en düşük öneme sahip hizmet kalitesi boyutunun ise fiziki kaynaklar olduğu sonucuna ulaşılmıştır (Shafii vd., 2016). Shanghai'de bulunan hastanelerin hizmet kalitesinin ölçülmesi amacı ile yapılan bir başka çalışmada ise güvenirliliğin (4.90/5.00) hizmet kalitesinin hastalarca en önemli boyutu olduğu ve bunu sırasıly empati (4.42/5.00), yeteneklilik (3.87/5.00), fiziki kaynaklar (3.73/5.00) ve heveslilik (3.56/5.00) boyutlarının takip ettiği bulunmuştur (Li vd., 2015).

\section{Marka Performansı}

Marka performansına ilişkin ortak bir tanım bulunmamakla birlikte, yapılan değerlendirmelerin önemli bir kısmı marka performansının işletmelerin stratejileri ve faaliyetleri sonucu oluştuğunu göstermektedir. Bir başka ifade ile marka performansı markanın gücü olarak da nitelendirilmektedir. Pazar payı, büyüme ve karlılık gibi rasyolar da marka performansı ile ilişkilendirilmektedir (Rasouli, 2016). Aaker (1991) markanın pazarlama çabalarının değerlendirilmesinde, işletmenin marka ile ilgili uzun dönemde başarısını 
ölçebilecek herhangi bir göstergenin olmadığını belirtmiştir. Bununla birlikte dağıtım, fiyat ve pazar payının performans ölçümünde göz önünde bulundurulması gerektiğini belirtmiştir. Nitekim, Dyson vd. (1996) de marka performansının markanın somut unsurları ile ilgili olduğunu belirtmişlerdir.

Lassar vd. (1995), marka performansını, tüketicinin ürün hakkındaki yargısı olarak değerlendirmiş ve markanın belirli koşullar altında, uzun süreli, kusursuz ve hatasız olarak işlevlerini gerçekleştirebilmesi olarak tanımlamışlardır. Ayrıca tüketicinin marka performansına ilişkin algısının oluşumunda markanın isminin, markanın vaat ettiği faydaların ve markanın kalitesinin etkili olduğunu belirtmişlerdir (Lassar vd., 1995). Raggio (2006) ürünün göreceli olarak iyi olmasına karşın, ürünün satın alınmamasının markanın performansını olumsuz olarak etkilediğini belirtmiştir. Ayrıca marka performansını marka denkliğinin bir unsuru olarak ele almış ve markanın performansının marka denkliğine katkı yaptığını belirtmiştir. Raggio (2006) marka performansını tüketicinin zihninde oluşan bir algı olarak ele almış ve her tüketicinin markanın vaat ettiği hizmetleri yerine getirmesi ile ilgili kendilerine özgü bir değerlendirme yaptığını öne sürmüştür. Bununla birlikte tüketicinin markanın performansına ilişkin yargııının ve bu yargının rakip markalar karşısındaki durumunun markanın performansı üzerinde etkili olduğunu belirtmiştir (Raggio, 2006).

Koç (2014) markanın satın alınmış olmasının, markanın performansının iyi seviyede olduğunu göstermediğini ve tüketicinin zihnindeki marka algısının marka performansının şekillenmesinde daha etkili olduğunu belirtmiştir. Foroudi (2018) bir otelin marka performansının otelin ismi, logosu ve markanın tutumu gibi fiziki özelliklerinden oluştuğunu belirtmiştir. Otel markasının bu niteliklerini sürekli olarak iyileştirilmesinin yeniden satın almayı olumlu etkileyeceğini ve otel markasının başkalarına tavsiye edilmesini sağlayacağını belirtmiştir (Forodi, 2018). Casidy, Wymer ve O'Cass (2018) ise marka performansının (1) satın alma sürecinde tüketicinin satın aldığı marka ile ilgili duygularından, (2) satın alınan marka için tüketicinin bütçesinden ayırdığı paydan (cüzdan payı) ve (3) tekrar ziyaret etme niyetinden oluştuğunu öne sürmüşlerdir. Millar ve Tesser (1986) ise tutum ve davranışların etkilerine ilişkin literatürde daha önce gerçekleştirilmiş olan çalı̧maların çoğunun çelişkili olduğunu belirtmiştir. Bu sebeple tutumun ya duygulardan ya da bilişsel bileşenlerden oluştuğunu öne sürmüşlerdir (Millar ve Tesser, 1986). Diğer taraftan bu çalışmada marka performansı tüketicilerin bakış açısından değerlendirilmeye çalışılmış ve marka denkliğinin bir bileşeni olarak ele alınmıştır.

Hastane otelciliği ile ilgili yapılan çalışmaların bazıları hastane performansını düşük ve yüksek maliyetli hastane performansı olarak iki grupta değerlendirmektedir. Bununla birlikte hastane maliyetlerinin ve sağlık bakım maliyetlerinin azaltılması bakımından hastanelerin belirli konularda uzmanlaşmalarının son derece etkili bir çözüm olduğu elde edilen sonuçlar arasındadır (Kim vd., 2003). Hastaneler ile ilgili yapılan çalışmalar hastanelerde markalama çalışmalarının hastanenin finansal performansına katkı yaptığını ve hastanenin rekabet yeteneğini arttırdığını ortaya koymuştur (Khosravizadeh vd., 2017). Hastane performansının değerlendirilmesinde kullanılan bir diğer ölçüm yöntemi ise PATH'dir (Performance Assessment Tool for Quality Improvement in Hospitals). PATH hastanelerde hizmet 
kalitesinin geliştirilmesine ve hastanelerin performansının değerlendirilmesine yönelik bir ölçme aracıdır. Çok boyutlu bir ölçüm yöntemi olan PATH'de hastaların bireysel sağlık durumları, hasta bakımında istenilen hedeflere ulaşılıp ulaşılmadığı, hastaların memnuniyet düzeyleri, hastaların onuru, gizliliği ve özerkliği, hastaların sağllk hizmetlerine erişimindeki eşitliği, çalışanların verimlilik düzeyleri ve maliyetler bu çalışmada dikkate alınan kriterler arasında yer almaktadır. Klinik ve idari performansın birlikte değerlendirildiği bu ölçüm yönteminde, hasta bakımında hedeflenen çıktılar olarak değerlendirilen klinik kalite hastanenin performansını etkilemektedir (Tengilimoğlu ve Toygar, 2013). Hastanelerde performansın yöneticilerin bakış açısından değerlendirilmeye çalışıldığı bir başka çalışmada ise kalite, maliyet ve finansal performans hastane performansının üç boyutunu oluşturmaktadır (Çınaroğlu ve Şahin, 2012).

\section{Araştırma Modeli ve Hipotezler}

Araştırma modelinin ortaya konulmasında öncelikle konu ile ilgili bir yazın taraması yapılmıştır. Yazın taraması sonucunda bazı boşluklar olduğu tespit edilmiştir. Hastaların bakış açısından sağlık otelciliğinin hizmet kalitesinin ve bu kalite algısının hastanenin performansına olan etkisinin ölçülmeye çalışıldığı bu çalışmanın ana kütlesi, hasta ve hasta yakınlarından oluşmaktadır. Bu bakımdan bu çalışma, hastaların bakış açısından sağlık otelciliğinde hizmet kalitesinin ölçülmesini ve verilen bu hizmetlerin performansının tespit edilmesini sağlayacaktır. Elde edilen sonuçların sağlık sektöründe yer alan işletmelere stratejik bir bakış açısı kazandıracağı düşünülmektedir.

Hasta ve hasta yakınlarının hastanelerden almış oldukları hizmetlerin kalitesinin ve hastanelerin marka performansının değerlendirilmeye çalışıldığı bu çalışma tanımlayıcı bir araştırmadır. Çalışmada veri toplama aracı olarak yüz yüze anket yöntemi kullanılmıştır. Kolayda örnekleme yönteminin kullanıldığı bu çalışma Mayıs 2018 ve Haziran 2018 tarihleri arasında gerçekleştirilmiştir. Edirne, Çorlu ve Tekirdağ’da bulunan özel ve kamu hastanelerinden hizmet almış 500 kişiye soru formu dağıtılmıştır. Yüz yüze anket yöntemi ile toplam 412 soru formu toplanmıştır. Katılımcıların soruları yanıtlarken hastanelerden almış oldukları hizmetleri (klinik hizmetler, otelcilik hizmetleri) düşünerek soruları yanttlamaları istenmiştir. Verilerin önemli bir kısmı bizzat hastanelerde yapılan anketlerden elde edilmiş olup; diğer kısmı ise bu hastanelerde hasta olarak bulunmuş ve hastanelerin otelcilik hizmetlerinden yararlanmış insanlardan elde edilmiştir. Araştırmanın evrenini Edirne, Çorlu ve Tekirdağ'da bulunan hastanelerden hizmet almış olan hasta ve hasta yakınları oluşturmaktadır. Ancak kaynak ve zaman kısıtllıkları ve evren büyüklügünün tam olarak bilinememesi gibi nedenlerle çalışmada Edirne, Çorlu ve Tekirdağ da bulunan hastanelerden hizmet almış olan yalnızca 412 hasta ve hasta yakınına ulaşılmıştır.

Çalışmada 57 kişilik bir katılımcı üzerinden veri toplanarak bir ön uygulama yapılmıştır. Ön uygulama sonucu hizmet kalitesi ölçeği için elde edilen Cronbach Alpha değeri .936; marka performansı ölçeği için elde edilen Cronbach Alpha değeri ise .941 olarak tespit edilmiştir. Bu değerler ise ölçeklere verilen yanıtların tutarlılığını göstermektedir. Verilerin analizinde ise çoklu regresyon analizi kullanılmıştır. 
Çalışmada Parasuraman, Zeithaml ve Berry (1985) tarafından geliştirilmiş olan hizmet kalitesi ölçeği kullanılmış olup, tüketicilerin hizmet kalitesine ilişkin algıları 5'li Likert tipi dereceleme ile ölçülmeye çalışılmıştır. Bu derecelendirmede 1 "kesinlikle katılmıyorum" 5 ise "kesinlikle katılıyorum" olarak değerlendirilmiştir. 22 ifadeden oluşan hizmet kalitesi ölçeğinin "fiziksel kaynaklar" boyutu 4 ifade ile, "yeteneklilik" 4 ifade ile, "empati” 5 ifade ile, "güvenirlilik" 5 ifade ile ve heveslilik ise yine 4 ifade ile ölçülmüştür. Çalışmanın marka performansı ölçeği ise Diokoa ve Sob’un (2012) marka denkliği ölçeğinden alınmış olup 4 ifade ile ölçülmüştür.

Hizmet kalitesi hakkında yapılan çalışmaların önemli bir kısmı bir firmanın hizmet kalitesinin firmanın performansını etkilediğini ortaya koymaktadır (Varinli vd., 2002; Bitner vd., 1990; Zeithaml vd., 1990). Hastane performansının değerlendirilmesinde kullanılan bir diğer ölçüm yöntemi ise PATH'dir. PATH'de hastanenin klinik kalitesinin hastanenin performansını etkilediği varsayılmıştır (Tengilimoğlu ve Toygar, 2013). Çınaroğlu ve Şahin (2012) hastane performansının kalite, maliyet ve finansal performans olmak üzere üç boyuta sahip olduğunu belirmiştir. Marangoz ve Biber (2007) işletmenin pazar performansını müşteri memnuniyeti, imaj ve hizmet kalitesi gibi değişkenlerle açıklamaya çalışmışlardır. Sultan ve Wong (2018) eğitim sektöründe yapmış oldukları bir çalışma sonucunda servis kalitesinin marka performansını, marka imajını ve davranışsal niyeti etkilediği sonucuna ulaşmışlardır. Nair (2016) ise turizm sektöründe yapmış olduğu bir araştırma sonucunda hizmet kalitesinin işletme performansını olumlu yönde etkilediğini tespit etmiştir. Ayrıca Zeithaml (2000) ile Duncan \& Elliot (2002) artan hizmet kalitesinin işletme gelirlerini, karlılığını ve satış hacmini olumlu yönde etkilediğini belirtmişlerdir. Akroush (2007) ise finans sektöründe yapmış olduğu araştırma sonucunda hizmet kalitesinin işletme performansını etkilediği sonucuna ulaşmıştır. Tüm bu açılamalar hizmet kalitesinin marka performansı üzerinde anlamlı bir etkisinin olduğuna işaret etmektedir.

H1: Hizmet kalitesi marka performansını pozitif yönde etkiler.

Önerilen model bakımından aralarında ilişki olduğu varsayılan araştırma modeli ise şöyledir:

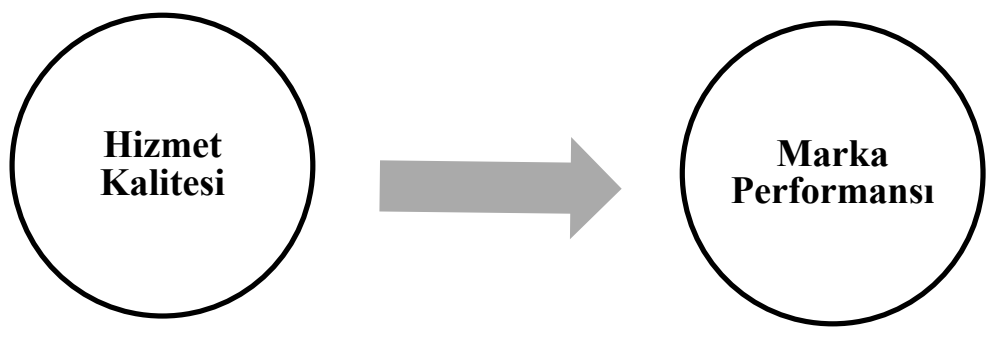

Şekil 1. Araştırma Modeli 


\section{Ölçme Araçlarının Güvenirlilik ve Geçerlilikleri}

Parasuraman vd.'nin (1985) çalışmalarından alınmış olan hizmet kalitesi ölçeği beş boyuttan oluşmakta ve toplam 22 soru ile tüketicilerin hizmet kalitesine ilişkin algıları ölçülmektedir. Hizmet kalitesi ölçeğinin beş boyutu: fiziksel kaynaklar (tangibles), güvenirlilik (reliability), heveslilik (responsiveness), yeteneklilik (assurance) ve empati (empathy) şeklindedir. Çalışmanın performans ölçeği ise Diokoa ve Sob’un (2012) beş boyutlu marka denkliği ölçeğinden alınmıştır. Hastalar ve hasta yakınları verilen hizmetin performansını 4 soru ile değerlendirmişlerdir. Bu ölçüm araçları uyarlaması yapılan kaynaklardan alınmıştır. Hizmet kalitesi ölçeği Yıldız ve Erdil'in (2013) çalışmalarından, marka performansı ölçüm aracı ise Unurlu'nun (2016) çalışmasından alınmıştır. Hizmet kalitesi ve tüketicinin hastane performansı ile ilgili algısı toplam 26 tutum sorusu ile ölçülmeye çalışılmıştır.

Tablo 2. Katılımcı Profiline İlişkin Bilgiler

\begin{tabular}{llrr}
\hline \multirow{3}{*}{ Cinsiyet } & & Frequency & Percent \\
\hline & Kadın & 199 & 48.3 \\
& Erkek & 213 & 51.7 \\
Toplam & 412 & 100.0 \\
Yaş & $18-25$ & 103 & 25.0 \\
& $26-35$ & 118 & 28.6 \\
& $36-45$ & 102 & 24.8 \\
Eğitim & 46 ve üzeri & 89 & 21.6 \\
& Toplam & 412 & 100.0 \\
& İlkokul & 44 & 10.7 \\
& Ortaokul & 77 & 18.7 \\
& Lise & 130 & 31.6 \\
& Ön lisans & 61 & 14.8 \\
& Lisans & 100 & 24.3 \\
Gelir & Toplam & 412 & 100.0 \\
& $1-2.99$ bin arası & 235 & 57.0 \\
& 3- 4.99 bin arası & 128 & 31.1 \\
& 5 bin ve üzeri & 48 & 11.7 \\
& Toplam & 411 & 99.8 \\
\hline
\end{tabular}

Tablo 2'de katılımcıların demografik niteliklerine ilişkin bilgilere yer verilmiştir. Tabloya göre katılımcıların \%48'i kadın, \%51'i erkektir. 18-25 yaş arası katılımcıların oranı \%25, 26-35 yaş arası katılımcıların oranı $\% 28,36-45$ yaş arası katılımcıların oranı $\% 24$ ve 45 yaş ve üzeri katılımcı oranı ise \%24'tür. Katılımcıların \%10'u ilkokul, \%18'i ortaokul, \%31' lise, \%14'ü ön lisans ve \%24'ü ise lisans mezunudur. Katılımcıların \%57'sinin aylık geliri 1- 2.99 bin arasında, $\% 31$ 'i 3 - 4.99 bin arasında ve \%11'inin aylık geliri ise 5 bin ve üzerindedir. 
Bir ölçme aracını oluşturan maddelerin birbirleri ile uyumu, benzerlikleri bir diğer ifade ile maddelerin homojenliği, ölçme aracının güvenirliliğine işaret etmektedir. Bu bakımdan hizmet kalitesi ve marka performansı ölçeğinin içsel tutarlılığının tespit edilmesi için, ölçme araçlarının Coronbach Alpha değerleri hesaplanmıştır. Ölçeklere ilişkin Coronbach Alpha değerleri Tablo 3'de yer almaktadır. Tablo 3'e göre araştırmaya konu olan ölçeklerin ve alt boyutlarının her birinin Coronbach Alpha katsayılarının literatürde sıklıkla kabul gören \%70'in üzerinde olduğu tespit edilmiştir. Bu değerler ise ölçeklerin iç tutarlılıklarının yüksek olduğuna işaret etmektedir (Kalayc1, 2010, s. 405).

412 katılımcıdan oluşan örneklem büyüklügünün faktör analizi için uygunluğu Kaiser-MeyerOlkin (K.M.O.) örneklem yeterliliği ölçütü ile değerlendirilmiştir. Hizmet kalitesi ölçeğinin 412 örneklem büyüklüğüne ilişkin K.M.O. değeri .951 olarak hesaplanmıştır. Bu değer araştırmaya ilişkin veri setinin faktör analizi için uygun olduğunu göstermektedir. (Kalayc1, 2010, s. 327). Çalışmanın marka performansı ölçeği için bulunan K.M.O. ölçütü ise .722'dir. Bu değer de araştırmaya ilişkin veri setinin faktör analizi için uygun olduğunu göstermektedir. (Kalaycı, 2010, s. 327). Bununla birlikte ölçeklerin her biri için Bartlett küresellik testi dikkate alındığında, hizmet kalitesi ölçeği için $\left(\chi^{2}=3781.231\right.$; $\left.\mathrm{df}=210 ; \mathrm{p}<0.001, \mathrm{p}<0.05\right)$ ve performans ölçeği için $(\chi 2=291.452 ; \mathrm{df}=6 ; \mathrm{p}<0.001, \mathrm{p}<0.05)$ hesaplanan değerlerin istatistiki olarak anlamlı olduğu tespit edilmiştir. Bartlett (1950) küresellik testini faktör analizinin bir önkoşulu olarak değerlense de Pett, Lackey ve Sullivan (2003), bu testi değişkenlerin tutarlılığının bir ölçütü olarak değerlendirmişlerdir. Tüm bu açıklamalar ölçeğin geçerliliğine işaret etmektedir. Tablo 3'de yapılan açılayıcı faktör analizi sonucu elde edilen maddelerin faktör yüklerine ve açıklanan varyans değerlerine yer verilmiştir.

Veri setinin faktör yapılarını belirlemek için ölçme araçlarının her birine (hizmet kalitesi ve performans) ayrı ayrı bir dizi açıklayıcı faktör analizi uygulanmıştır. Temel bileşenler analizinin ve döndürme yöntemi olarak da Varimax’ın kullanıldığı açıklayıcı faktör analizinde öz değeri 1'in üzerinde olan maddeler baz alınmıştır. Faktör yükü .40'nin altında olan ve binişiklik gösteren hizmet kalitesi ölçeğinden 3 madde analizden çıkarılmıştır. Hizmet kalitesi için yapılan açıklayıcı faktör analizi sonucunda açıklanan varyansı en yüksek olan alt boyut sırasıyla empati (\%16), yeteneklilik (12), heveslilik (\%12), fiziki kaynaklar (\%11) ve güvenirlilik (\%9) şeklidedir. Performans ölçeği için yapılan açıklayıcı faktör analizi sonucunda ise faktör yükü 40’’n altında olan bir madde olmadığı ve binişiklik söz konusu olmadığı için herhangi bir madde analizden çıarılmamıştır. Performansın açıklanan varyansı ise \%53’tür. Hizmet kalitesinin açıklanan varyansı ise \%61 olarak tespit edilmiştir. 


\section{Tablo 3. Ölçme Araçlarının Faktör Yükleri ve Açıklanan Varyans Değerleri}

\begin{tabular}{|c|c|c|c|}
\hline Ölçekler ve Alt Boyutları & $\begin{array}{r}\text { Faktör } \\
\text { Yükü }\end{array}$ & $\begin{array}{l}\text { Açıklanan } \\
\text { Varyans }\end{array}$ & $\begin{array}{l}\text { Coronbach } \\
\text { Alpha }\end{array}$ \\
\hline \multicolumn{4}{|l|}{ Hizmet Kalitesi Ölçeği } \\
\hline $\begin{array}{l}\text { Hastane çalışanlarının çalışma saatlerinin hastalara uygun şekilde } \\
\text { düzenlenmesi. }\end{array}$ & .648 & 15.976 & .792 \\
\hline Hastane çalışanlarının hastalarla tek tek ilgilenmesi. & .641 & & \\
\hline Hastane çalışanlarının hastalarla çok yakından ilgili olması. & .618 & & \\
\hline Hastane çalışanların hastaların özel isteklerini anlamaları. & .566 & & \\
\hline Hastane çalışanların hastaların menfaatini her şeyin üstünde tutmaları. & .565 & & \\
\hline \multicolumn{4}{|l|}{ 2. Yeteneklilik } \\
\hline $\begin{array}{l}\text { Hastane çalışanlarının hastaların sorularına cevap verecek bilgiye sahip } \\
\text { olmaları. }\end{array}$ & .708 & 12.422 & .748 \\
\hline Hastane çalışanlarının hastalar üzerinde güven duygusu uyandırmaları. & .671 & & \\
\hline $\begin{array}{l}\text { Hastaların hastane çalışanları ile olan etkileşimlerinde kendilerini } \\
\text { güvende hissetmeleri. }\end{array}$ & .613 & & \\
\hline \multicolumn{4}{|l|}{ 3. Heveslilik } \\
\hline $\begin{array}{l}\text { Hastane çalışanlarının verilecek olan hizmetin tam olarak ne zaman } \\
\text { gerçekleşeceğini hastalara bildirmesi }\end{array}$ & .690 & 12.209 & .745 \\
\hline Hastane çalışanlarının hastalara süratli bir şekilde hizmet vermeleri. & .677 & & \\
\hline Hastane çalışanlarının hastalara her zaman yardımcı olmak istemeleri. & .630 & & \\
\hline $\begin{array}{l}\text { Hastane çalışanlarının hiçbir zaman hastaların isteklerini } \\
\text { cevaplayamayacak kadar meşgul olmamaları. }\end{array}$ & .561 & & \\
\hline \multicolumn{4}{|l|}{ 4. Fiziksel Kaynaklar } \\
\hline Hastanede kullanılan eşya ve malzemelerin görünüşü & .704 & 11.162 & .742 \\
\hline Hastanenin modernliği & .656 & & \\
\hline Hastane binasının ve ofislerinin görünüşü & .612 & & \\
\hline Hastane çalışanlarının hijyeni ve görünüşü & .603 & & \\
\hline \multicolumn{4}{|l|}{ 5. Güvenirlilik } \\
\hline Hastane çalışanlarının sözlerini yerine getirmedeki tutarlılığı & .778 & 9.453 & .761 \\
\hline Hastane çalışanlarının doğru hizmeti ilk seferde vermeleri & .537 & & \\
\hline $\begin{array}{l}\text { Hastane çalışanlarının bir hizmeti daha önceden söyledikleri zamanda } \\
\text { vermeleri. }\end{array}$ & .527 & & \\
\hline \multicolumn{4}{|l|}{ Performans } \\
\hline Hastanenin sorunsuz bir hastane olması sebebi ile tercih edilmesi & .776 & 53.449 & .705 \\
\hline Hastanenin üstün hizmet sunması & .752. & & \\
\hline Hastaların hastaneden üstün performans beklemesi & .720 & & \\
\hline Hastanenin performansının oldukça iyi bulunması & .672 & & \\
\hline
\end{tabular}

\section{Hipotezlerin Test Edilmesi}

Bağımsız değişken olan hizmet kalitesi ile bağımlı değişken olan marka performansı arasındaki ilişkinin incelenmesi için çoklu regresyon analizi yapılmıştır. Tablo 4'de yer alan değerler, modelin ve tahminlenen katsayıların istatistiki olarak anlamlı olduğunu göstermektedir. Beta katsayıları bağımsız değişkenin (hizmet kalitesi) ya da bağımsız değişkenin alt boyutlarından her birinin (fiziki kaynaklar, güvenirlilik, heveslilik, yeteneklilik ve empati) bağımlı değişken üzerindeki (marka performansı) oransal olarak açıklama gücüne işaret etmektedir. Yapılan analizler neticesinde, hizmet kalitesinin marka performansındaki değişkenliğin (düzeltilmiş 
$\mathrm{R}^{2}$ ) \%66’’nı açıladı̆̆ 1 tespit edilmiştir. Tablo 4'de ise modele ilişkin bağımsız değişkenin bağımlı değişken üzerindeki açıklama gücünü gösteren $\beta$ katsayılarına ve bu katsayıların anlamlılık değerlerine yer verilmiştir. Ayrıca tabloda araştırma modeline ilişkin çoklu doğrusallık değerlerine de yer verilmiştir. Mason ve Perrault (1991) tolerans değeri .10'dan küçük olan ve VIF skorunun 10 ve 10 'un üzerinde olan değerlerin problem yarattı̆̆ını ve modelin tekrar değerlendirilmesi gerektiğini belirtmişlerdir. Bu bakımdan söz konusu modelin tolerans ve VIF değerleri dikkate alındığında çoklu doğrusallık sorununun olmadığ tespit edilmiştir.

Tablo 4. Çoklu Regresyon Analizi Sonucu

\begin{tabular}{|c|c|c|c|c|c|c|c|c|c|c|}
\hline Model & $\begin{array}{l}\text { Standardize } \\
\text { Edilmemiş } \\
\text { Beta Değeri }\end{array}$ & $\begin{array}{l}\text { Standart } \\
\text { Hata }\end{array}$ & $\begin{array}{l}\text { Standardize } \\
\text { Edilmiş } \\
\text { Beta Değeri }\end{array}$ & $\begin{array}{l}T \\
\text { Değeri }\end{array}$ & $\begin{array}{l}F \\
\text { Değeri }\end{array}$ & $\begin{array}{l}\text { Serbestlik } \\
\text { Derecesi }\end{array}$ & $\begin{array}{l}\text { Düzeltilmiş } \\
R \text { Kare }\end{array}$ & $\begin{array}{l}\text { Anlamlthlık } \\
\text { Değeri }\end{array}$ & $\begin{array}{l}\text { Tolerans } \\
\text { Değeri }\end{array}$ & $\begin{array}{l}\text { VIF } \\
\text { Değeri }\end{array}$ \\
\hline & & & & & 395.180 & 5 & .664 & .000 & & \\
\hline $\begin{array}{l}\text { Fiziki } \\
\text { kaynaklar }\end{array}$ & .223 & .021 & .254 & 10.371 & & & & & .408 & 2.453 \\
\hline Güvenirlilik & .105 & .031 & .111 & 3.427 & & & & & .373 & 2.681 \\
\hline Heveslilik & .163 & .032 & .166 & 5.071 & & & & & .433 & 2.310 \\
\hline Yeteneklilik & .188 & .030 & .197 & 6.319 & & & & & .633 & 1.581 \\
\hline Empati & .233 & .028 & .239 & 8.318 & & & & & .408 & 2.453 \\
\hline
\end{tabular}

Tablo 4'e göre fiziki kaynakların $(\beta=0.25, \mathrm{p}<0.05)$, güvenirliliğin $(\beta=0.11, \mathrm{p}<0.05)$, hevesliliğin $(\beta=0.16, p<0.05)$, yetenekliliğin $(\beta=0.19, p<0.05)$ ve empatinin $(\beta=0.23, p<0.05)$ marka performansı üzerinde pozitif bir etkisi bulunmaktadır. Diğer taraftan $F$ testi $(395.180, p<0.00)$ modelin istatistiksel olarak anlamlı olduğuna işaret etmektedir. Düzeltilmiş belirtme katsayısı dikkate alındığında (Adj. $\mathrm{R}^{2}$ ), bağımsız değişkenlerin (fiziki kaynaklar, güvenirlilik, yeteneklilik, empati, heveslilik) bağımlı değişkendeki değişkenliğin (marka performansı) \%66’sını açıkladığı tespit edilmiştir. $\mathrm{Bu}$ veriler ışığında $\mathrm{H} 1$ hipotezinin verilerle desteklendiği sonucuna ulaşılmıştır. Analiz sonucu elde edilen regresyon eşitliği ise şöyledir: Marka Performansı = .521 +.223 Fiziki Kaynaklar + .105 Güvenirlilik + .163 Heveslilik + .188 Yeteneklilik + .233 Empati.

\section{Sonuç}

Hizmetlerin karmaşık ve çok yönlü doğası, stratejik olarak hizmetlerin hangi yönlerinin geliştirilmesi gerektiği ile ilgili çelişkiler yaşanmasına neden olmuştur. Sağlık hizmetleri ise hizmet sektörünün en temel unsurları arasında yer almaktadır. Bu bakımdan sağlık sektöründe yer alan hastanelerin performanslarının iyileştirilmesi ve hizmet kalitelerinin geliştirilmesi için dizi yöntem, araç strateji ve hatta tüm bu unsurları kapsayan bir vizyona, felsefeye ihtiyaç duyulmaktadır. Dolayısıyla hastanelerin çok yönlü bir çaba içerisinde olmaları gerekmektedir. Bu bakımdan bu çalışma, hastaların bakış açısından hastanelerin hizmet kalitesini ve hastanelerin performansını ölçmeye çalışmıştır. Elde edilen sonuçların hastanelerin hizmet kalitesi ile ilgili yaşanan sorunları çözmesi ve özellikle hizmet kalitesinin hangi unsurlarının hastalar için daha önemli olduğunu tespit edilmesi bakımından önem taşımaktadır. 
Sağlık otelciliği olarak da adlandırılan hastane otelciliği, tıbbi hizmetler ile birlikte hasta ve hasta yakınlarına konaklama, yiyecek içecek hizmeti sunan hastaneler olarak değerlendirilmektedir. Sağlık otelciliği, ayakta ve yatarak tedavi edilen tüm hastalara yönelik olup, hastanın hastaneye giriş yapıp hastaneden ayrıldığı süre zarfınca almış oldukları bütün hizmetleri kapsamaktadır (Kozak ve Gülenç, 2017). Bu çalışmada sağlık otelciliğinde hizmet kalitesinin hastanenin performansı üzerindeki etkisinin olup olmadığı ölçülmeye çalışılmıştır. Bu amaçla hasta ya da hasta yakını olarak söz konusu illerde bulunan hastanelerden sağlık hizmeti almış olan insanların konu ile ilgili değerlendirmeleri dikkate alınmıştır. Yapılan regresyon analizi sonucunda fiziki kaynakların katsayısı .254 olarak tespit edilmiştir. Bir başka ifade ile fiziki kaynaklardaki bir birimlik artış marka performansında .254 birimlik artışa neden olmaktadır. Hizmet kalitesinin bir diğer alt boyutu olan güvenirliliğin katsayısı ise .111 olarak tespit edilmiştir. Bir başka deyişle güvenirlilikteki bir birimlik artış marka performansında .111 birimlik bir artış meydana getirecektir. Hizmet kalitesinin heveslilik alt boyutunun katsayısı ise .166 olarak tespit edilmiştir. Kısaca, heveslilikteki bir birimlik artış marka performansında .166 birimlik artışa neden olmaktadır. Yeteneklilik alt boyutunun katsayısı ise .197 olarak tespit edilmiştir. Özetle, yeteneklilikteki bir birimlik artış marka performansında .197 birimlik bir artış meydana getirecektir. Hizmet kalitesinin empati alt boyutunun katsayısı ise .239 olarak tespit edilmiştir. Diğer bir ifade ile empatideki bir birimlik artış marka performansında .239 birimlik artışa neden olmaktadır.

\section{Kuramsal Çıktılar}

Hastaların ve hasta yakınlarının beş boyutlu hizmet kalitesi ölçeği (fiziki kaynaklar, güvenirlilik, yeteneklilik, empati, heveslilik) ile ilgili tutumlarının oluştuğu tespit edilmiştir. Katılımcıların, marka performansına ilişkin tutumlarının oluştuğu da elde edilen tespitler arasındadır. Değişkenlere ilişkin Cronbach's Alpha değerleri .792-.705 arasında değişmektedir. Hizmet kalitesi ölçeği boyutlarının ortalamaları dikkate alındığında fiziki kaynaklar boyutunun ortalamas1 4.6214, güvenirlilik boyutunun ortalaması 4.3247 , heveslilik boyutunun ortalaması 4.4099, yeteneklilik boyutunun ortalaması 4.6184 ve empati boyutunun ortalaması ise 4.1874 olduğu tespit edilmiştir. Marka performansı ile katılımcıların değerlendirilmelerinin ortalamaları ise 4.5641 olarak tespit edilmiştir. Yapılan çoklu regresyon analizi sonucunda ise bağımlı değişkenlerin (fiziki kaynaklar, güvenirlilik, yeteneklilik, empati, heveslilik) bağımsız değişkendeki (marka performansındaki) değişkenliğin \%66’sını açıkladı̆̆ı tespit edilmiştir. Marka performansındaki değişkenliği açıklayan değişkenler önem sırasıyla fiziki kaynaklar (\%25), empati (\%23), yeteneklilik (\%19), heveslilik (\%16) ve güvenirlilik (\%11) şeklindedir.

Çalışma kapsamında hizmet kalitesi için gerçekleştirilen faktör analizi neticesinde hastaların hastanelere yönelik en çok empati tutumlarının, en az ise güvenirlilik tutumunun oluştuğu tespit edilmiştir. İkinci sırada yeteneklilik, üçüncü sırada heveslilik, dördüncü sırada ise fiziki kaynaklar yer almaktadır. Pekkaya ve İmamoğlu (2017) ise en önemli hizmet kalitesi boyutunun güvenirlilik ve yeteneklilik olduğunu; fiziksel kanıtlar ve empati boyutunun ise en az öneme sahip olduğunu tespit etmişlerdir. Hizmet kalitesinin fiziki kaynaklar, empati ve güven boyutlarının ise hasta memnuniyeti ve sadakati ile ilgili olmadığı tespit edilmiştir. Bir başka çalışmada ise hastaların hizmet kalitesinin tüm boyutlarına ilişkin tutumlarının oluştuğu ve alt boyutların önemlilikleri ile ilgili dikkate değer bir farklılık oluşmadığ 
vd., 2016). Chakravarty (2011) ve Untachai (2013) ise yapmış oldukları araştırmalar sonucunda hastaların hizmet kalitesine ilişkin yalnızca fiziki kaynaklar ve heveslilik boyutunda tutumlarının oluştuğunu, güvenirlilik, empati ve yetenekliliğe ilişkin tutumlarının ise oluşmadığını tespit etmişlerdir. Devebakan ve Aksaraylı (2003) tarafından yapılan bir çalışmada hastalarca hizmet kalitesinin en önemli boyutunun güvenirlilik ve güven olduğu tespit edilmiştir. Hizmet kalitesinin fiziksel kaynaklar ve empati boyutu ise hastalarca en az öneme sahip olan hizmet kalitesi boyutu olarak tespit edilmiştir. Bu çalışma kapsamında tespit edilen sonuçların söz konusu literatür ile eksiksiz bir uyum içerisinde olduğunu söylemek mümkün değildir. Bu durumun olası nedeni hastaların verilen hizmetin kalitesini sağlıklı bir şekilde değerlendirecek teknik bilgiye sahip olmamalarıdır. Bununla birlikte tüm bu çalı̧maların farklı coğrafyalarda gerçekleştirilmiş olması da elde edilen sonuçların farklı olmasına neden olmaktadır.

Marka performansındaki değişkenliği açıklayan hizmet kalitesinin alt boyutları önem sırasıyla fiziki kaynaklar, empati, yeteneklilik, heveslilik ve güvenirlilik şeklindedir. Bu sonuçlar ise hasta ve hasta yakınlarının hastanenin performansına ilişkin yargılarının oluşumunda öncelikle hastanenin fiziki kaynaklarının ve hastane çalışanlarının empati yeteneklerinin etkisinde kaldıklarını göstermektedir. Bu etkiyi çalışanların empati, yeteneklilik ve heveslilik tutumları takip etmektedir. Bu sonuçlar daha önce gerçekleştirilen çalışmalar ile tutarlılık göstermektedir (Itumalla, 2012; Li vd., 2015; Meesala \& Paul, 2018). Nitekim Kotler ve Keller (2012) hizmet sektöründe işletmelerin kalitelerini daha çok fiziki ortam, çalışanlar, kullanılan iletişim araçları, sembol, slogan ve fiyat gibi somut unsurlarla ifade ettiklerini öne sürmüştür. Bu bakımdan elde edilen sonuçlar mevcut kuramla örtüşmektedir.

\section{Uygulamaya Dönük Çıkarımlar}

Elde edilen sonuçlar dikkate alındığında hastane yöneticileri özellikle güvenirlilik ve sonrasında fiziki kaynaklar konusunda hastanelerini geliştirmek durumundadırlar. Nitekim hastaların bu boyutlarla ilgili tutumları düşük düzeyde oluşmuştur. Çalş̧anların hastalara karşı daha duyarlı olmaları ve hastaların kendilerini güvende hissedebilecekleri ortamlar yaratmaları hastanenin hizmet kalitesinin iyileştirilmesi için son derece önemli olacaktır. Hastalara verilen hizmetlerin hızlandırılması, randevuların daha etkili bir biçimde kullanılması, kalitenin güvenirlilik ile ilgili yönüne katkı sağlayacaktır. Bunun yanı sıra, hastane yönetimleri hastanelerinin fiziki donanımları, kullandıkları makine ve malzemeler, çalışanların hijyeni, binanın temizliği ve görünüşü gibi konular bakımından daha hassas olmaları gerekmektedir. Hastanelerin temizlik hizmetlerini dışarıdan profesyonel bir temizlik şirketinden almaları önerilmektedir. Hastalarca kullanılan sirkülasyon alanlarının, hastane çalışanlarınca kullanılan sirkülasyon alanlarından ayrılması ve hatta ziyaretçiler için ayrı sirkülasyon alanlarının oluşturulması hastanelerin temizlik zafiyetlerini önemli ölçüde giderecektir. Ortak kullanım alanlarının belirli periyotlarla düzenli olarak temizlenmesi de hijyen ile ilgili sorunların giderilmesine ve böylece hastanenin fiziki kaynaklar ile ilgili algının iyileşmesine katkı sağlayacaktır. 
Çalışmadan elde edilen bir diğer tespit ise hizmet kalitesinin fiziki kaynaklar ve empati boyutlarının hastanenin performansı ile ilgili tutumun şekillenmesinde son derece önemli olduğudur. Çalışanların empati yeteneklerinin geliştirilmesi bakımından hastanede çalışma saatlerinin hastalara uygun bir biçimde düzenlenmesi, çalışanların hastaların özel isteklerini anlamak için çaba sarf etmeleri, hastanın menfaatlerini her şeyin üstünde tutmaları hastanenin marka performansına katkı sağlayacaktır. Bu açıdan hastane yönetimi, çalışanların bu konulardaki duyarlılıklarını arttırmak için, çalışanların iş başı ve iş dışı eğitimlere katılmalarına ortam ve olanaklar sağlayabilirler. Fiziki kaynaklar ile ilgili algıyı iyileştirmek ve böylece hastanenin performansını geliştirmek isteyen hastane yöneticileri hijyen konusundaki hassasiyetlerini arttırmaları gerekmektedir. Hastane binasının ve ofislerinin diş görünüşü, modernliği ve kullanılan malzemeler hastaların kalite algısını önemli ölçüde şekillendirmektedir. Hastane yöneticilerinin bu konulardaki duyarlılıklarını arttırmaları, konuya daha ciddi bir biçimde eğilmeleri gerekmektedir. Ayrıca hastane yöneticileri hizmet kalitesinin beş boyutu bakımından güçlü oldukları yönlerini (empati) bir pazarlama stratejisi olarak kullanmaları ve zayıf yönleri (güvenirlilik, fiziki kaynaklar) bakımından da kendilerini geliştirmeleri önerilmektedir. Bunun yanı sıra, hizmet kalitesi ile ilgili ölçümlerin periyodik olarak yapılması hastanenin hizmet kalitesi bakımından kendini yönlendirmesinde etkili olacaktır.

Sağlık otelciliğinde fiziki kaynaklar bakımından hastanenin hijyeni, yeterli aydınlatma, hastane binasının ve ofislerinin özellikleri, hastanenin sahip olduğu teknik donanımları, görevlilerin fiziki görünüşleri ve kullanılan ekipmanların modernliği, hastanenin marka performansına katkı sağlayacaktır. Hasta ve hasta yakınları için makul danı̧̧ma saatleri, hastaların spesifik ihtiyaçlarının anlaşılmaya çalışılması için ekstra çaba sarf edilmesi ve çalışanların iletişim yeteneklerinin arttırılması hastanenin marka performansını olumlu yönde etkileyecektir. Hastane çalı̧anlarının verdikleri sözleri tutmadaki tutarlılığı; hasta ve hasta yakınlarının sorunlarını çözmek için gösterdikleri samimi ilgi; görevlilerin ilgili hizmeti tam ve zamanında verebilmeleri ve bu konudaki istekliliği; çalışanların görevlerini inanarak yerine getirmeleri hastanenin kalite ile ilgili algısına katkı sağlayacaktır. Diğer taraftan çalışanların hastaların sorunlarını çözmedeki samimiyetleri, hasta ve hasta yakınlarına her zaman yardımcı olmak istemeleri; hasta ve hasta yakınlarının güven duygusunun şekillenmesinde etkili olacaktır. Çalışanların hasta ve hasta yakınlarına karşı nazik olmaları, hastaların mahremiyetini her şeyin üstünde tutmaları hastanenin hizmet kalitesi ile ilgili algıyı destekleyecektir.

Sonuçlar göz önünde bulundurulduğunda, marka performanslarını yükseltmek isteyen hastane yöneticileri öncelikle hastanelerinin fiziki kaynaklarına sonrasında ise çalışanlarının empati yeteneklerini geliştirmeye odaklanmalıdırlar. Yeteneklilik, heveslilik ve güvenirlilik ise marka performansı açısından üzerinde durulması gereken diğer hizmet kalitesi boyutlarıdır. Analizler neticesinde hastaların hizmet kalitesinin fiziki kaynaklara ilişkin tutumunun düşük düzeyde oluştuğu ve hastanenin marka performansı ile ilgili algısını etkileyen en önemli değişkenin ise yine fiziki kaynaklar olduğu tespit edilmiştir. Bu bakımdan hastane yöneticileri hastane binasının modernliği ile ilgili birtakım yatırımlar yapmalıdırlar. Yöneticiler hastane binasının, hastanede kullanılan malzeme ve ekipmanların görünüşü ve çalışanlarının hijyeni konusunda olanaklarını geliştirmelidirler. 


\section{Akademik Öneriler}

Hizmet kalitesi ve marka performansı arasındaki ilişkinin incelendiği bu çalışma, teorik ve yönetimsel katkılara sahip olmasına karşın, birtakım sınırlılıkları da bulunmaktadır. Bu bakımdan gelecekte yapılacak çalışmalar için öneriler şöyledir:

- Gelecekte yapılacak çalışmalar, araştırma modelinde yer alan değişkenlerin etkisinin daha yakından incelenebilmesi için yaş, eğitim, cinsiyet gibi demografik niteliklerin etkisini ölçmeyi düşünebilirler.

- Parasuraman vd. 'nin (1985) hizmet kalitesi ölçeğinin kullanıldığı bu çalışma, farklı hizmet kalitesi ölçekleri kullanılarak da gerçekleştirilebilir. Nitekim, Parasuraman vd. 'nin (1985) hizmet kalitesi ölçeğinin sağlık sektörünün kendine has niteliklerini tam olarak ölçemediği ve hatta bu ölçeğin sağlık sektörü için çok genel ve yüzeysel kaldığ düşünülmektedir.

- Anlık bir araştırma olarak gerçekleştirilen bu çalışmanın belirli periyotlarla tekrarlanması araştırmanın genelleştirilmesine katkı sağlayacaktır.

- Öncelikle araştırmanın örneklem büyüklüğünün çalışmanın genelleştirilebilmesi için yeterli olmakla birlikte; bu değerlendirmelerin yalnızca araştırma kapsamında değerlendirilen hastaneler için geçerli olduğu gözden kaçırılmamalıdır.

- Gelecekteki çalışmalar hastaların hastane seçimlerinden ziyade doktor seçimlerine odaklanabilirler.

- Hastaların hastane ile ilgili tutumlarının şekillenmesinde doktorların etkisi de bir başka araştırma konusu olarak incelenebilir.

\section{Kaynakça}

Aaker, D. A. (1991). Managing Brand Equity. New York: The Free.

Akdag, H., Kalayc1, T., Karagöz, S., Zülfikar, H., \& Giz, D. (2014). The evaluation of hospital service quality by fuzzy MCDM. Applied Soft Computing, 23, 239-248.

Akroush, M. (2007). Exploring the Mediation Effect of Service Quality Implementation on the Relationship between Service Quality and Performance: Managers' Perceptions in the Banking Industry in Jordan, Global Business and Economics Review, 10(1), 98-122.

Aksaraylı, M. ve Devebakan, N. (2003). Sağlık İşletmelerinde Algılanan Hizmet Kalitesinin Ölçümünde SERVQUAL Skorlarının Kullanımı ve Özel Altınordu Hastanesi Uygulamas1, Dokuz Eylül Üniversitesi Sosyal Bilimler Enstitüsü Dergisi, 5(1), 38-54.

Anderson, C. ve Zeithamal, C.P. (1984). Stage of the Product Life Cycle, Business Strategy, and Business Performance, Academy of Management Journal, 27, 5-24. 
Arslan, A. ve Kırık, A. M. (2013). Sosyal Paylaşım Ağlarında Konum Belirleme Ölçeğinin Geçerlilik ve Güvenirlilik Çalışması, Öneri Dergisi, 10(40), 223-231.

Bayrak, B. (2007). Yüksek Öğretim Kurumlarından Beklenen Hizmet Kalitesi ve Hizmet Kalitesinin Algılanmasına Yönelik Bir Çalışma. (Yayınlanmamış Doktora Tezi). Marmara Üniversitesi Sosyal Bilimler Enstitüsü, İstanbul.

Bitner, M. J., Booms, B. H. ve Tetreault, M. S. (1990). The Service Encounter: Diagnosing Favorable and Unfavorable Incidents, Journal of Marketing, 54(1), 71-84.

Bülbül, H. ve Demirer, Ö. (2008). Hizmet Kalitesi Ölçüm Modelleri Servqual ve Serperf'in Karşılaştırmalı Analizi. Selçuk Üniversitesi Sosyal Bilimler Dergisi, 20, 181-198. http://dergisosyalbil.selcuk.edu.tr/susbed/article/viewFile/362/344

Büyüköztürk, Ş. (2011). Veri Analiz El Kitabı, Ankara: Pagem Akademi.

Casidy, R., Wymer, W. and O'Cass, A. (2018). Enhancing Hotel Brand Performance though Fostering Brand Relationship Orientation in the Minds of Consumers. Tourism Management, 66, 72-84. https://doi.org/10.1016/j.tourman.2017.11.008

Chakravarty, A. (2011). Evaluation of Service Quality of Hospital Outpatient Department Services. Medical Journal Armed Forces India, 67(1), 221-224.

Choi, K-S., Cho, W-H., Lee, S., Lee, H. and Kim, C. (2004). The Relationships Among Quality, Value, Satisfaction and Behavioral Intention in Health Care Provider Choice: A South Korean Study. Journal of Business Research, 57(8), 913-921. https://doi.org/10.1016/S0148-2963(02)00293-X

Çalık, M. (2010). Bütünleşik Pazarlama İletişimi ve Marka Performansı Arasındaki İlişkinin Analizi. (Yayınlanmamış Doktora Tezi). Sakarya Üniversitesi/Sosyal Bilimler Enstitüsü, Sakarya.

Çetin, S. ve Kuzucu, H. (2019). Servqual Ölçeği ile Yaşlı Bakımevlerinde Hizmet Kalitesinin Ölçümü, Selçuk Üniversitesi Bilim ve Teknoloji Dergisi, 7(2), 509-523. DO10.15317/Scitech.2019.215

Çınaroğlu, S. ve Şahin, B. (2012). Yönetici Değerlendirmelerine Göre Hastanelerde Performans Ölçümü, Hacettepe Să̆lık İdaresi Dergisi, 15(1). 
Dalgıç, A. (2013). Hizmet Sektöründe Hizmet Kalitesinin Ölçümü ve Hizmet Kalitesini Etkileyen Faktörler: Antalya'da Hizmet Kalitesi Ölçümüne Yönelik Bir Uygulama, Adnan Menderes Üniversitesi Sosyal Bilimler Enstitüsü, Yüksek Lisans Tezi.

Demirer, Ö. \& Bülbül, H. (2014). Kamu ve Özel Hastanelerde Hizmet Kalitesi, Hasta Tatmini ve Tercihi Arasındaki İlişki: Karşılaştırmalı Bir Analiz, Amme İdaresi Dergisi, 47(2), 95 119.

Diokoa, L. A. N. \& Sob, S. A. (2012). Branding Destinations versus Branding Hotels in a Gaming Destination-Examiningthe Nature and Significance of Co-Branding Effects in the Case Study of Macao. International Journal of Hospitality Management, 31(2), 554563. https://doi.org/10.1016/j.ijhm.2011.07.015

Duncan, E. \& Elliot, G. (2002). Customer Service Quality and Financial Performance among Australian Retail Financial Institutions, Journal of Financial Service Marketing, 7(1), 25 41.

Dyson, P., Farr, A. \& Hollis, N. (1996). Understanding, Measuring and Using Brand Equity. Journal of Advertising Research, 36(6), 9-21. https://elibrary.ru/item.asp?id=2857096

Foroudi, P. (2018). Influence of Brand Signature, Brand Awareness, Brand Attitude, Brand Reputation on Hotel Industry' Brand Performance. International Journal of Hospitality Management, https://doi.org/10.1016/j.ijhm.2018.05.016

Grönros C. (1984). A Service Quality Model and its Marketing Implications. European Journal of Marketing, 18(4), 36-44. https://doi.org/10.1108/EUM0000000004784

Gummesson, E. (1987), The New Marketing Developing Long Term Interactive Relationship, Long Range Planing, 20(4), 10-20. http://dx.doi.org/10.1108/07363769510095270

Gummesson, E. \& Gronroos C. (1987). Quality of Products and Services: A Tentative Synthesis between Two Models. Sweden: Science Research Service.

Handayani, P. W., Hidayanto, A. N., Sandhyaduhita, P. I. ve Ayuningtyas, K. D. (2015). Strategic Hospital Services Quality Analysis in Indonesia, Expert Systems with Applications, 42(6), 3067-3078. https://doi.org/10.1016/j.eswa.2014.11.065 
Itumalla, R. (2012). Information Technology and Service Quality in Health Care: an Empirical Study on Private Hospitals in India, Int. J. Innov., Manag. Technol., 3(4), 433-436.

İmamoğlu, Ö. ve Pekkaya, M. (2017). Hastane Hizmet Kalitesinde Serqual Boyutlarının Önem Derecelerinin Belirlenmesi, International Journal of Management Economics and Business, 13, 607-616.

Kalaja, R., Myshketa, R. \& Scalera, F. (2016). Service Quality Assessment in Health Care Sector: The Case of Durres Public Hospital, Procedi - Social and Behavioral Sciences, $235,557-567$.

Kalaycı, Ş. (2010). Spss Uygulamalı Çok Değişkenli İstatistik Teknikleri, Ankara: Öz Baran.

Karakoç, F. Y. ve Dönmez L. (2014). Ölçek Geliştirme Çalışmalarında Temel İlkeler, Tıp Ĕ̈itimi Dünyası, 40, 39-49. http://dergipark.gov.tr/download/article-file/199275

Kerlinger; F.N. (1973). Foundations of Behavioral Research. (Second ed.) New York: Holt, Rinehart and Winston.

Khosravizadeh O, Vatankhah S, Maleki M. (2017). A Systematic Review of Medical Service Branding: Essential Approach to Hospital Sector. Ann Trop Med Public Health, 10(5), 1137-1146.

Kim, H. B., Kim W. G. ve An J. A. (2003). The Effect of Consumer-Based Brand Equity on Firms' Financial Performance, Journal of Consumer Marketing, 20(4), 335-351. https://doi.org/10.1108/07363760310483694.

Koç, M. E. (2014). Marka Topluluklarında Algılanan Faydalar ile Marka Performansı Arasındaki İlişki, (Yayınlanmamış Doktora Tezi). Haliç Üniversitesi/Sosyal Bilimler Enstitüsü, İstanbul.

Koçak, C.; Albayrak, S. A. ve Duman, N. B. (2014). Hemşirelerin Bakım Verici Rollerine İlişkin Tutum Ölçeği Geliştirilmesi: Geçerlik ve Güvenirlik Çalışması, Hemşirelikte Eğitim ve Araştırma Dergisi, 11(4), 16-21.

Kotler, P. (2000). Marketing Management. New Jersey: Prentice Hall.

Kotler, P. ve Keller, K. L. (2012). Marketing Management. New Jersey: Prentice Hall. 
Kozak, M. ve Gülenç, S. (2017). Sağlık Otelciliği Hizmetlerinin Değerlendirilmesi: Eskişehir Hastaneleri Örneği. Manas Sosyal Araştırmalar Dergisi, 6(5), 1-16. http://oaji.net/articles/2017/2519-1521547132.pdf.

Lassar, W., Mittal, B. And Sharma, A. (1995). Measuring Customer-Based Brand Equity. Journal of Consumer Marketing, 12, 11-19. https://doi.org/10.1108/07363769510095270.

Li M., Lowrie D. B., Huang C. Y., Lu X. C., Zhu Y. C. Z., Wu X. H., Shayiti M., Tan Q. Z., Yang H. L., Chen S. Y., Zhao P., He S. H., Wang X. R. ve Lu H. Z. (2015). Evaluating Patients' Perception of Service Quality at Hospitals in Nine Chinese Cities by Use of the ServQual Scale, Asian Pacific Journal of Tropical Biomedicine, 5(6), 497-504. https://doi.org/10.1016/j.apjtb.2015.02.003.

Marangoz, M. \& Biber, L. (2007). İşletmelerin Pazar Performansı ile İnsan Kaynakları Uygulamaları Arasındaki İlişkinin Araştırılmasına Yönelik Bir Çalışma. Doğuş Üniversitesi Dergisi, 8(2), 202-217.

Mason, C. H. and Perreault J. W. D. (1991) Collinearity, Power and Interpretation of Multiple Regression Analysis, Journal of Marketing Research, 28(3), 268-80.

Meesala, A. ve Paul, J. (2018). Service Quality, Consumer Satisfaction and Loyalty in Hospitals: Thinking for the Future, Journal of Retailing and Consumer Services, 40, 261269. https://doi.org/10.1016/j.jretconser.2016.10.011.

Millar, M.G. ve Tesser, A. (1986). Effects of Affective and Cognitive Focus on the AttitudeBehavior Relation. Journal of Personality and Social Psychology, 51(2), 270-276. DOI: 10.1037/0022-3514.51.2.270.

Nair, G. (2016). Impact of Service Quality on Business Performance in Hospitality Industries: An Empirical Study. Journal of Tourism, Hospitality and Sports, 17, 10-28.

Neşe, A., Turan, A. ve Çizmeci, B. (2017). A Study of Service Quality Assessment for Patients: Case of Ahi Evran University Training and Research Hospital Emergency Services, Journal of Current Researches on Business and Economics, 7(2), 407-420.

Newcome, L. N. (1997). Measuring of Trust in HealthCare. Health Affair, 16, 50-51. DOI 10.1377/hlthaff.23.4.124 
Normann, R. (1991). Service Management: Strategy and Leadership in Service Businesses. Chichester, England: Wiley.

Papatya, G., Papatya, N., \& Hamşığlu, A. B. (2012). Algılanan Hizmet Kalitesi ile Hasta Memnuniyeti: İki Özel Hastanede Karşılaştırmalı Bir Araştırma. Kırıkkale Üniversitesi Sosyal Bİlimler Dergisi, 2(1), 87-107.

Parasuraman, A., Zeithaml, V. ve Berry, L. L. (1985). A Conceptual Model of Service Quality and Its Implications for Future Research. Journal of Marketing, 49(4), 41-50. http://www.jstor.org/stable/1251430

Pett, M.A., Lackey, N.R. and Sullivan, J. J. (2003). Making Sense of Factor Analysis: The Use of Factor Analysis for Instrument. USA: Sage.

Raggio, R.D. (2006). Three Essays Exploring Consumers' Relationships With Brands and The Implications For Brand Equity. (Yayınlanmamıs Doktora Tezi). Ohio Devlet Üniversitesi, Ohio.

Rasouli, R. (2016). Tüketici Temelli Marka Değeri ile Perakendeci Temelli Marka Değerinin Karşılaştırılması ve Perakendeci Temelli Marka De ğerinin Marka Performansına Etkisi

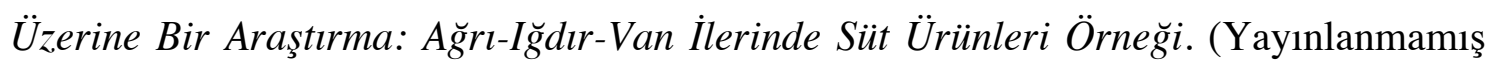
Doktora Tezi). Atatürk Üniversitesi Sosyal Bilimler Enstitüsü, Erzurum.

Shafii, M., Rafiei, S., Abooee, F., Bahrami, M. A., Nouhi, M., Lotfi, F. ve Khanjankhani, K. (2016). Assessment of Service Quality in Teaching Hospitals of Yazd University of Medical Sciences: Using Multi-criteria Decision Making Techniques, Osong Puplic Health and Research Perspectives, 7(4), 239-247. https://doi.org/10.1016/j.phrp.2016.05.001

Sultan, P. \& Wong, H.Y. (2019). How Service Quality Affects University Brand Performance, University Brand Image and Behavioural Intention: The Mediating Effects of Satisfaction and Trust and Moderating Roles of Gender and Study Mode, Journal of Brand Management, 26, 332. https://Doi.Org/10.1057/S41262-018-01313

Şahin, Ş. ve Şen. S. (2017). Hizmet Kalitesinin Müşteri Memnuniyeti Üzerine Etkisi, Uluslararası Sosyal Araştırmalar Dergisi, 10(52). Doi: http://dx.doi.org/10.17719/jisr.2017.1971 
Tarcan, G.Y., Karahan, A. \& Tarcan, M. (2018). The Effect of Hospital Innovations on Perceived Service Quality: Public Hospital Example, AJIT-e, 9(32). DOI:10.5824/13091581.2018.2.009.x

Tengilimoğlı, D. ve Toygar, S. (2013). Hastane Performansının Ölçümünde PATH Yöntemi, Sosyal Güvenlik Dergisi, 3(1), 50-78.

Tomes A. E. \& Ng, S. C. P. (1995). Service Quality in Hospital Care: the Development of an in-Patient Questionnaire. Int $J$ Health Care Qual Assur, 8(3), 25-33. DOI: $10.1108 / 09526869510089255$

Untachai, S. (2013). Modeling Service Quality in Hospital as a Second Order Factor, Thailand. Procedia - Social and Behavioral Sciences, 88, 118-133.

Unurlu, Ç. (2016). Marka Performansının, Kültürün ve Marka Kişiliğinin Marka Sadakati Üzerine Etkisi: İstanbul'daki Beş Yıldızlı Otel İşletmelerinde Bir Uygulama Trakya Üniversitesi Sosyal Bilimler Enstitüsü, İşletme Anabilim Dalı, Edirne.

Varinli, İ., Güllü, K. ve Babayiğit, S. (2002). Perakendecilikte Hizmet Kalitesi ve Tüketicilerin Kalite Değerlendirmelerine Yönelik Bir Araştırma, Pazarlama Dünyası Dergisi, 4.

Williams, S. J. (1994). Patient Satisfaction: a Valid Concept? Soc. Sci. Med., 38(4), 509-516. https://doi.org/10.1016/0277-9536(94)90247-X

Yıldız, O. ve Erdil, T. S. (2013). Türkiye Havayolu Yolcu Taşımacılığı Sektöründe Hizmet Kalitesinin Karşılaştırmalı Ölçümlenmesi. Öneri Dergisi, 10, 89-100.

ZeIthaml, V., Parasuraman, A., ve Berry, L. L. (1990). Delivering Service Quality: Balancing Customer Perception and Expectations, New York: The Free.

Zeithaml, V. (2000). Service Quality, Profitability, and the Economic Worth of Customers: What We Know and What We Need to Learn, Journal of Academy of Marketing Science, $28(1), 67-85$. 